\title{
Prince Juan and Calisto: Reflections on a His- torical Antecedent for a Literary Archetype
}

\author{
Samuel Sánchez y Sánchez \\ Davidson College
}

\section{Celestina: An Eclectic Tapestry of Sources and Influences}

"A text,» Roland Barthes reminds us, "consists not of a line of words, releasing a single 'theological' meaning (the 'message' of the Author-God), but of a multi-dimensional space in which are married and contested several writings, none of which is original: The text is a fabric of quotations, resulting from a thousand sources of culture» (1986: 52-53). This kind of textual mélange permeates the pages of Celestina in such a way that «su principal ystoria o ficción toda junta» blends with the «delectables fontezicas de filosophía» that emerge from a wide range of textual and oral sources. The study of the literary influences and sources of Rojas' work has proven to be a fertile field that has kept researchers active for decades. Indeed as time has gone by, Celestina continues to engage scholars by means of the diverse range of literary and non-literary genres, Western and non-Western geographical origins, historical periods, and languages that are woven into the literary tapestry of Rojas' text.

The web of sources, references, and allusions in Celestina has attracted critical attention since at least mid- $16^{\text {th }}$ century when an anonymous learned author wrote a book known as Celestina comentada with the goal of identifying many of the quotes and references found in Rojas' work. In 1905 Menéndez Pelayo made a systematic examination of genres and authors in Celestina in his study Orígenes de la novela. Castro Guisasola's 1924 study, Observaciones sobre las fuentes literarias de "La Celestina," remains a mandatory reference when examining the literary and non-literary sources in Celestina. In 1929 the work of Fernando Valle Lersundi opened the doors of Rojas' personal library, which in turn allowed for the opportunity to peek into the vast literary cosmos of Celestina. ${ }^{1}$ These

1.- For more on Rojas' library see: Víctor Infantes (2007), «Fernando de Rojas: el lector desvelado (en su caligrafía). De nuevo sobre el «inventario» de sus libros», Celestinesca, 31 , pp. 103-118; Víctor Infantes (1998), «Los libros 'traydos y viejos y algunos rotos' que tuvo el 
studies reconstruct the avid reading practices and creative process that underlie Celestina's tapestry of references and influences which seems to multiply with every new attentive reading.

In this regard, critics have examined the presence and the influence in Celestina of Petrarch's works in Latin, penitential books, Western and non-Western literary works, classic philosophy, medical treatises, and law manuals, among many others. ${ }^{2}$ Thanks to this considerable body of scholarly research, we have come to understand the ways in which the works by Aristotle, Socrates, Plato, Virgil, Ovid, Boethius, Seneca, Boccaccio, Petrarch, Ali Ibn Ahmad, Avicenna, Vatsayana, Sayj Nfzawi, Juan Ruiz, López de Ayala, el Tostado, Juan del Encina, Diego de San Pedro, Diego de Quiñones, Jorge Manrique, Nicolás Núñez, Juan de Mena, or Rodrigo Cota, just to name a few, are present in Celestina. When considering the eclectic nature of authors and texts that inhabit Celestina, the conclusion that we reach seems to be clear: Celestina defies generic conformity by building textual bridges both within and beyond its own cultural boundaries of production.

The present essay contributes to the ongoing scholarly effort to shed light onto the sources that inspired Rojas' creative process by examining Celestina's immediate cultural context of production: Salamanca, 14971499. ${ }^{3}$ In this essay I would like to suggest that Prince Juan, the firstborn

bachiller Fernando de Rojas nombrado autor de la obra llamada Celestina", Bulletin Hispanique, 100, pp. 7-51; and Fernando Valle Lersundi (1929), «Testamento de Fernando de Rojas, autor de La Celestina», Revista de Filología Española, 16.3, pp. 66-388.

2.- The intricacies of the influences and sources of Celestina have been widely examined in works such as: Enrique Fernández Rivera (2015), «El De secretis mulierum en La Celestina y en la biblioteca de Fernando de Rojas», Neophilologus, 99, pp. 407-418; Ínigo Ruiz Arzálluz (2000), "Fuentes» in Fernando de Rojas (y "antiguo autor»). La Celestina, eds. Francisco Jobera et al, Barcelona, Crítica, pp. cvi-cxxiii; Michel García (1997), «Las fuentes literarias castellanas del glosador de Celestina», Celestinesca, 21, pp. 49-64; Francisco Márquez Villanueva (1993), Orígenes y sociología del tema celestinesco, Barcelona, Antropos; Arno Gimber (1992), "Los rufianes de la primera Celestina: Observaciones acerca de una influencia literaria.» Celestinesca, 16.2, pp. 6476; L. Fotherhill-Pyane (1988), Seneca and Celestina, Cambridge, Cambridge University Press; Dennis P. Seniff (1986), «Bernardo Gordinio's Lilio de Medicina: A Possible Source of Celestina?», Celestinesca, 10.1, pp. 13-18; Keith Whinnom (1988), «El género celestinesco: origen y desarrollo", Academia Literaria Renacentista, V, Literatura de la época del Emperador, ed. Víctor García de la Concha, Salamanca, Universidad de Salamanca, pp. 119-130; Ivy Corfis (1984), "Fernando de Rojas and Albrecht Von Eyb's Margarita poetica», Neophilologus, 68.2, pp. 206-213; Alan Deyermond (1975), The Petrarchan Sources of "La Celestina», Westport: Greenwood Press; and María Rosa Lida de Malkiel (1962), La originalidad Artística de "La Celestina», Buenos Aires, Editorial Universitaria.

3.- Stephen Gilman (1972), The Spain of Fernando de Rojas. The Intellectual and Social Landscape of "La Celestina», Princeton: Princeton UP and Maxime Chevalier (1976), Lectura y lectores en la España del siglo XVI y XVII, Madrid, Turner continue to be indispensable references for gaining an understanding of the socio-cultural context of Celestina and Fernando de Rojas. See also Ínigo Ruiz Arzalluz (1996), «El mundo intelectual del antiguo autor: las Auctoritates Aristetolis en la Celestina primitiva", Boletín de la Real Academia Española, 76, pp. 264-284; Francisco Bautista (2008), «Realidad social e ideología en La Celestina», Celestinesca, 32, pp. 37-49; José Luis Canet 
son to the Catholic Kings Ferdinand and Isabella, who died in Salamanca in 1497 may well have served as a model for Calisto. More specifically this essay compares the legendary love life and model death of Prince Juan to the erotic passion and bad death of Calisto from the perspective of excess and exemplarity in order to suggest that the prince may have been a source for Calisto. Additionally, this essay explores what is to be learned about representations of extreme love and exemplary death when examined within the context of the didacticism that characterized late medieval Iberia. By bringing together the literary representations of Prince Juan and Calisto that construct each of them as protagonists of outlandish love and exemplary death, this essay illuminates the ways in which the literary and didactic functions of excess were negotiated by Fernando de Rojas to reconcile the apparently contradictory instructions for how to both love and die well at the dawn of modernity in Iberia.

Love and death are the two themes most often associated with excess and exemplarity throughout the literature of the Middle Ages. Excess is usually associated with the overstepping the limits of moderation by crossing social, physical or psychological boundaries; with decadence, the illicit, lack of control. Excess itself entails the departure from custom and reason and evokes an extravagant violation of law, decency, or morality in a manner of outrageous conduct. Exemplarity refers to the quality of being fit to serve as a model or pattern for imitation: by virtue of the medieval genre of the exemplum the meaning of "exemplary" hinged between positive models and cautionary tales. Exemplary conduct, thus, could also serve as a warning. As illustrated by the comparison between Prince Juan and Calisto, excess becomes a conceptual touchtone that legitimates a literary taste for extravagance in love within the didacticism that pervades late medieval Iberia in relation to death.

\section{Living to Love: Exemplarity and Hyperbolic Sexuality}

In the literary arena of $15^{\text {th }}$ Century Iberia exemplarity and excess were negotiated within a didactic trend that aimed to teach both how to love well and to die well. At this time, the cultural model of dying well was determined by the Ars Moriendi, the popular how-to guide by which the Church did its best to teach people how to die properly: at home surrounded by family after having received the appropriate rites. Under the long shadow of the Ars Moriendi, $15^{\text {th }}$ Century Iberia also saw the emergence of the Spanish sentimental romance which disseminated a taste for

(1997), "La Celestina y el mundo intelectual de su época," in Cinco siglos de Celestina: Aportaciones interpretativas, Rafael Beltrán and José Luis Canet (eds.), Valencia, Universidad de Valencia, pp. 43-60; and Ignacio Arellano y Jesús M. Usunáriz (eds.) (2003), El mundo social y cultural de "La Celestina», Actas del Congreso Internacional, Universidad de Navarra, Iberoamericana Vervuert. 
exaggerated expressions of love that revolved around the trope of love as a malady, as a disease that could be cured but could also be fatal. These authors crafted a cultural model of love with prototypical characters and scenarios in which loving well frequently resulted in death. Along these lines, the Cancionero poets took the love-death connection to extremes and spared no details to make everyone blush with their highly eroticized compositions. From this perspective, poems, ballads, and romances displayed exemplary characters who simultaneously served as role models in amatory matters and model Moriens of a didactic template of death. This is precisely what brings together both Prince Juan and Calisto: The most exemplary lover seems to be a dead one.

Within these parameters the literary representations of Prince Juan and Calisto characterize them as two exorbitant lovers who were the protagonists of two different kind of exemplary deaths: one to be imitated, the other to be avoided. In having their identities built on excess in love and didacticism in death, they both share the privilege of being part of the collective imaginary of late medieval Iberia. When compared, these two cases suggest that both love and death are two concepts that oscillate between hyperbolic performances and exemplary lessons.

This happens to be the case of one of late medieval Iberia's most legendary lovers: Prince Juan. He was born in Seville in June 1478. Despite his precarious health as a child, he always accompanied his parents Ferdinand and Isabella in their campaigns as a way to protect the future monarch from negative influences. After a long period of illness, Prince Juan was named heir to the throne in December 1492 at which point the queen took personal care in the education of her son. She surrounded the young prince with the most learned people of the kingdom in order to instruct him in his future tasks as king: the Dominican Fray Diego de Deza, professor at the University of Salamanca and Bishop of Zamora, Salamanca, and Jaén; the Italian humanist Pedro Mártir de Anglería; Lucio Marineo Sículo; Fray Andrés de Miranda, Fray Pedro de Ampudia, Beatriz Galindo, and the Geraldino brothers. In November 1495, Prince Juan married by proxy Princess Margarite, daughter of the emperor Maximilian. She arrived in Castile in March 1497. Six months later, at the age of 19, Prince Juan would die. Cause of death? The one thing for which neither parents nor physicians hold a cure: excessive love. His untimely demise along with his supposedly hyperbolic sexual ardor sparked the dissemination of the legend that constructed the young heir as the "prince who died of love.» As chronicles show, beyond the personal loss for the Catholic Kings, Prince Juan's death was an ominous symbolic demise and a political blow for the kingdom. The prince was buried in Ávila and, ac- 
cording to Pedro Mártir de Anglería, along with his body was buried «la esperanza de España entera» (López de Toro 1953: 346). ${ }^{4}$

Excess and hyperbole had always been present in the life of the prince. For example, in 1490 and 1491, Prince Juan suffered from a strange disease puzzling doctors who then prescribed a diet based on an unusual ingredient that could not be found in sufficient quantities in Castile. Therefore, in June 1490 the Catholic King wrote to Diego de Torre, his advisor in the kingdom of Valencia exhorting him «lo antes que ser podiere nos enbieys cinquenta tortugas que han de servir para el yllustrísimo Príncipe nuestro fijo, porque con las otras que le truxeron, como sabeys se falla mejor» (Pérez-Bustamante and Calderón Ortega 1999: 60). One month later, the king again wrote to his advisor regarding the turtles because "cunple mucho haverlas presto, vos encargamos o mandamos que si al recebir de la presente non las hoviéssedes enviado lueguo, recebiendo esta sin alguna dilaçión nos las envieys que por lo aquesto havemos mandado spachar el presente correo, el qual paguareys» (Pérez-Bustamante and Calderón Ortega 1999: 61).

The purpose of the turtles was to make juice as it was believed that the meat and blood from these animals had curative qualities. As the basis of the prince's treatment, this remedy depended on a rare supply. The medical discourse around the turtles as the main ingredient for the prince's medicine was quickly supplemented by a hyperbolic narrative that transformed these animals into high quality commodities. In December 1491 King Ferdinand wrote again to Diego de Torre. In this letter, we learn that:

Las tartugas que fueron embiadas para el yllustrísimo Prinçipe nuestro fijo son acabadas y es grande inconveniente que no las haya, por el grande beneficio que la speriencia muestra fazer en su persona. E porque en ello va lo veys, havemos acordado por solo esto fazeros este mensajero encarguando y mandandovos que en reçibiendo la presente, sin dilaçion de una sola hora

4.- For a complete view on the life and death of Prince Juan see Gabriel Maura Gamazo (2000), El Principe que murió de amor. Don Juan, primogénito de los Reyes Católicos, Madrid, Alderabán Ediciones; Ángel Alcalá and Jacobo Sanz (1999), Vida y muerte del principe don Juan, Valladolid, Consejería de Educación y Cultura de la Junta de Castilla y León. For an in depth view of the historical background and political projection of Prince Juan see Damián González Arce (2016), La casa y corte del principe don Juan (1478-1497), Archivos y Publicaciones Scriptorium; Francisco Martínez López (2007), La casa del Principe de Asturias: D. Juan, heredero de los Reyes Católicos, Madrid, Dykinson; Bruno Aguilera Barchet (1998), "La figura constitucional del Príncipe de Asturias» and Rogelio Pérez-Bustamante (1998), "La figura de don Juan, Príncipe de las Españas, y la Unión de las Coronas en el V Centenario (1497-1997)", in La figura del principe de Asturias en la corona española, Madrid, Editorial Dykinson, pp. 9- 44; pp. 89-106; and Tarsicio Azcona (1992), «El príncipe don Juan, heredero de los Reyes Católicos en el v Centenario de su nacimiento (1478-1497), Cuadernos de Investigación Histórica, pp. 219-243. 
busqueys e faguays busquar quantas tartugas se puedan haver en esa ciudad y Reyno y aquéllas lueguo nos enbieys sin dilaçion alguna, e de aquí adelante esteys aperçibido de haver cada mes quarenta dellas y embiárnoslas a buen recaudo sin falleçer, e si quizá en esa ciudad y Reyno no se pudiessen haver tantas, embyareys a mayor cautela la que va con la presente a nuestro procurador real de Mallorca en que le mandamos que lo que por vos le fuere scrito sobre embiar tartugas de aquel Reyno e vos lo faga e ponga por obra como si nos se la scriviésemos. (Pérez-Bustamante and Calderón Ortega 1999: 66)

The excessive nature of the monarch's command made the task close to impossible for the governor of Mallorca. By way of the king's mandate the turtles to produce the healing juice for Prince Juan were transformed into the objects of a highly unusual medical treatment thus inserting their consumer in the realm of excess. In addition to their practical use, the turtles acquired a symbolic value that differentiated the prince's disease, and subsequently, the prince himself as an extravagant individual: the distinctive use of the meat and blood of turtles emphasized the uniqueness of their consumer who, by receiving such an extreme medical remedy, was characterized by hyperbole.

Such an exquisite elixir restored the young prince but could not save him from his death in October 1497, which, as contemporary sources show, was tainted with an air of sexual excess. If during his delicate childhood the prince's body had been inscribed with the discourse of disease, as a teenage boy excessive eroticism took possession of his body along with his public image. Both discourses converged in the young body of the prince as the cause of his death, which according to the most creative accounts of the time was caused by excessive marital relations with his wife, Princess Margarite.

For Pedro Mártir de Anglería, Princess Margarite was the perfect embodiment of Eros and Thanatos. We have only to read his description of the young princess in his letter to Cardenal de Santa Cruz in June 1497 to realize this fatal convergence:

Si la vieras, te harías una idea de que estabas contemplando a la misma Venus. Cual en belleza, porte y edad pudo Marte desear a Citerea, tal desde Flandes nos la enviaron, sin desfigurar con ningún afeite, sin arreglar con ningún arte. Dirías que era Oritia escapada de las manos del helado Boreas. Pero temblamos al pensar que todo esto algún día nos acarree a nosotros la infelicidad y la perdición a España. (López de Toro 1953: 334) 
In fact, it was the Italian humanist who originated the legend of a prince who served as an embodiment of the literary trope of «love as illness.» In the same letter to Santa Cruz, Anglería writes:

nuestro joven, ardiendo en amor consiguió de sus padres se le dispusiera el lecho matrimonial, llegando por fin, a los deseados abrazos con madama Margarita. Pero habían pasado sólo un par de meses y ya la multiplicación de los deseados abrazos y el continuado hervor del placer tenían alarmados a los médicos del príncipe y al propio rey Fernando, aunque no a la Católica reina, acostumbrada a la natural robustez de su marido. (López de Toro 1953: 334)

An increasingly alarmed Anglería continues his report noting in reference to Princess Margarite that "preso del amor de la doncella ya está demasiado pálido nuestro joven Príncipe» (López de Toro 1953: 334). He continues his salacious gossip by adding

Los médicos juntamente con el Rey, aconsejan a la Reina que alguna vez que otra aparte a Margarita del lado del Príncipe, que los separe y les dé treguas, alegando que la cópula tan frecuente constituye un peligro para el Príncipe. Una y otra vez la ponen sobre aviso para que observe cómo se va quedando chupado y la tristeza de su porte; y anuncian a la Reina que, su juicio suyo, se le pueden reblandecer las médulas y debilitar el estómago. Le instan a que, mientras le sea posible corte y ponga remedio al principio. No adelantan nada. Responde la Reina que no es conveniente que los Hombres separen a quienes Dios unió con el vínculo conyugal. ${ }^{5}$ (López de Toro 1953: 34)

As constructed by these accounts, Prince Juan was no more than a hormone-fueled teenager consumed by the inordinate pursuit of sexual pleasure, which ended up devastating his body. The excessive sexual ardor of the prince, however, not only had fatal consequences for his body but was also an alarming sign for the destiny of his soul. This lack of physical moderation and restraint was a dangerous activity for one's soul, a danger directly addressed by Alonso Ortiz, chaplain to the royal family, in his Diálogo sobre la educación del Príncipe don Juan (1497). In the chapter entitled "De cómo debemos cuidar el cuerpo» Ortiz, in reference to Prince

5.- The separation of lovers was in fact one of the remedies that doctors prescribed for the disease of love. As Francisco López de Villalobos explains in his Sumario de la Medicina (1498) this is the eighth rule in order to achieve a cure for love: «le aparten con gran diligencia daquella señora como en pestilencia se apartan los hombres del ayre dañado» (Herrera 1973: 41). 
Juan, warns Queen Isabella that when it comes down to one's body everything must be conducted "con discreción para que nada resulte excesivo [...]; de hecho los que se dedican con mucha frecuencia a los trabajos corporales debilitan el alma. Hay en la realidad, como canta Horacio, discreción y medida y existen limitaciones; por esto tenemos que exhortar siempre al muchacho para que se someta a la medida en cualquier cosa» (Bertini 1983: 167). In this regard, Prince Juan's lustful love fits perfectly with the literary model used by the ecclesiastical convention of the time to condemn disproportionate passions "capaces de destruir al hombre, haciéndole perder su libre albedrío, razón y las potencias intelectivas, llegando incluso hasta la muerte física» (Canet 1996: 5). Moreover, medieval penitential books and confessionals reminded their audience that excessive love and sexual ardor yielded to illicit unions, lust, and adultery. ${ }^{6}$ In fact, as José Luis Canet points out, "todos los canonistas y manuales de confesores insisten en estos aspectos negativos de la actividad sexual, pero sobre todo en contra de la pasión amorosa, que esclaviza al hombre, haciéndolo de señor siervo» (1996: 8).

The numerous references that chroniclers and poets make to the prince's sexual ardor strongly suggest that his hyperbolic sexuality had been inscribed into the collective imaginary of his contemporaries as an example of an extravagant conduct. In fact, as Diego Catalán points out, «la actitud del confesor del príncipe (fray García de Padilla) y del canónigo Ortiz ante ese placer está, desde luego, aún muy lejos de la moral matrimonial que exigiría la Iglesia a los casados después de la Contrarreforma. Pero, aunque en los tiempos de los Reyes Católicos las buenas costumbres dieran más lugar a la sensualidad, el erotismo de la joven pareja de príncipes resultaba llamativo" (1998: footnote 99, 67). Contemporary accounts confirm this excess in the prince's love life. According to these sources, Prince Juan lacked control not only over his passions but also over his public image: the heir to the crown was thus perceived as an insatiable lover who died from excessive ardor.

Two years after Prince Juan died of love Celestina emerged in the literary arena of late medieval Iberia introducing another voracious lover: Calisto. His taste for hyperbole in amatory matters is well established from the very beginning of the text. When Calisto meets Melibea in matter of seconds he - just as happened with Prince Juan - is overcome by passion tinged with fatality. After being 'infected' with Melibea's love, Calisto returns home to 'die' as a good courtly lover: "iAnda, anda, malvado!," Calisto commands Sempronio, «abre la cámara y endereça la cama! [...]

6.- Along these lines, as José Luis Canet notes, Saint Jerome qualified as adulterers those husbands who "aman demasiado ardientemente a sus mujeres» because «en relación a la esposa de otro todo amor es vergonzoso; en relación a la suya, el amor excesivo» (1996: 9). These ideas «se mantendrán en el siglo XVI, insistiendo que el amor con la mujer deber ser contenido, si no convierten a su propia esposa en prostituta» (Canet 1996: footnote 11, p. 10). 
Cierra la ventana y dexa la tiniebla acompañar al triste y al desdichado la ceguedad. Mis pensamientos tristes no son dignos de luz. $¡ \mathrm{O}$ bienaventurada muerte aquella que desseada a los afligidos viene!» (Severin 1989: 88) ${ }^{7}$

In a moment of excess and exaggeration reminiscent of hormone-driven adolescent infatuation, Calisto is literally preparing himself to die of love as if he were staging a secular version of the conventional deathbed, which allows Rojas to subvert both the ecclesiastical guidelines for dying well and the courtly love rules for loving well. ${ }^{8}$ Sempronio cannot believe what he is seeing; that is, he is witnessing right in front of his eyes a scene out of a sentimental romance (specifically Cárcel de amor by Diego de San Pedro) in which the wretched lover dies of love after being rejected by his beloved. With a combination of awe, frustration, and irony he asserts: «No me engaño yo, que loco está este mi amo» (Severin 1989: 92).

Both master and servant engage in a rather comical dialogue in order to determine the cause of Calisto's malady. After a series of probing questions about the young lover's physical health, psychological well-being, and religious beliefs, Sempronio exclaims: «no es más menester, bien sé de qué pie coxqueas» in reference to Calisto's lust for Melibea (Severin 1989: 93). The humoristic effect achieved by presenting Calisto's exaggerated expression of love is evident. In fact, as José Luis Canet notes, this kind of vices «son el elemento humorístico y ridículo pero al mismo tiempo reprobatorio de ciertos comportamientos sociales esclavizados por su sexualidad inferior» (1996: 4). However, along with the audience's perception of the literary representation of Calisto's behavior as eccentric and hyperbolic, as Dennis Seniff proposes, a close examination of Bernardo Gordonio's Lilio de Medicina suggests that "Calisto's love malady would have been viewed as a fully documented clinical story by a learned audience» (1986: 13). In fact, as we read in Sumario de la Medicina (1498) by Doctor Francisco López de Villalobos —Rojas' former classmate in Salamanca-, love was an illness that, as Prince Juan's and Calisto's cases confirm, had

\section{7.- All references to Celestina come from Dorothy S. Severin's 1998 edition.}

8.- As José Luis Canet notes, Rojas' criticism takes place «bajo una forma cómica y agradable, incluso con una clara parodia a los comportamientos extremos de las ficciones sentimentales en boga. Bajo este punto de vista no podemos olvidar que La Celestina surge en un ambiente claramente universitario y por lo tanto es el lugar idóneo para que unos profesores procedentes de la burguesía media critiquen los modelos culturales de una sociedad aristocrática apartada de la realidad circundante que se recluyen mediante sus ficciones en modelos corteses del pasado" (Canet 1997: 55). As it has been well documented, Celestina may be read as an open criticism against nobility and one of its defining characteristics: courtly love. See Yolanda Iglesias (2009), Una nueva mirada a la parodia de la novela sentimental en 'La Celestina,' Madrid, Iberoamericana/Vervuert; June Hal Martin McCash (2001), "Calisto y la parodia del amante cortés," in Estudios sobre "La Celestina," ed. Santiago López Ríos Moreno, pp. 475-545; María Eugenia Lacarra (1989), "La parodia en la ficción sentimental en 'La Celestina', Celestinesca 13.1, pp. 11 30; Dorothy Severin (1984) «La parodia del amor cortés en 'La Celestina',» Edad de Oro III, pp. 275-279; Dorothy Severin (1980) "Parodia y sátira en 'La Celestina'," Actas del VI Congreso de la Asociación Internacional de Hispanistas, Toronto, University of Toronto, pp. 695-697. 
a negative effect on judgement, strength, wisdom, prudence, and reason, but could be cured by following specific guidelines (Herrera 1973: 40-41)

As Andreas Capellanus had established centuries earlier in his treatise on Courtly Love, love is "una especie de pasión o sufrimiento innato que se deriva de ver y meditar excesivamente en la belleza del sexo contrario, y que le hace a uno desear por encima de todo los abrazos de la otra persona y cumplir de común acuerdo los preceptos del amor en los brazos de la persona amada» (Arias 1992: 9). As the chaplain explains, this passion emerges "cuando un hombre ve a una mujer apta para el amor y de belleza conforme a su gusto, enseguida comienza a desearla en su corazón» (Arias 1992: 9). After that the lover "comienza a considerar la apostura de la dama y a pensar en cada uno de sus miembros, a imaginar lo que estará haciendo, y a escudriñar los secretos de su cuerpo, deseando servirse lo más posible de cada una de estas partes» (Arias 1992: 10). Calisto clearly exhibits these symptoms. After seeing Melibea in her garden, he symbolically breaks up her body into pieces in the well-known description that the dejected lover provides of Melibea's body to Sempronio. Calisto starts with the young woman's hair which is more beautiful and shinier than "las madexas del oro delgado que hilan en Aravia» and "su longura hasta el postrero assiento de sus pies; después crinados y atados con la delgada cuerda, como ella se los pone, no ha mas menester para convertir los hombres en piedras» (Severin 1989: 100). The lover continues describing each of Melibea's body parts and concludes that «aquella proporción que veer yo no pude, no sin dubda por el bulto de fuera juzgo incomparablemente ser mejor que la que Paris juzgó entre las tres diesas» (Severin 1989: 101).

Following the paradigm of Princess Margarite's beauty, Eros and Thanatos converge in that of Melibea as well. First, Melibea's hairstyle blond and long - evokes the classical pattern of beauty related to Venus; however, in Melibea's description, the erotic force of her hair is tainted by the allusion to the destructive power of Medusa with venomous snakes (an essential symbol throughout Rojas' text) instead of hair. In addition to this love/death connection, Calisto relates Melibea's beauty to the Judgement of Paris, an omen that, as Dorothy Severin points out, presages the disastrous end of the young lover (1989: footnote 50,101).

The fatal philocaptio of which both Prince Juan and Calisto are victims is what leads to excess. As Saint Jerome pointed out: «El amor por lo bello es un pérdida de la razón, casi la locura: vicio horrible muy poco conveniente a un espíritu sano [...] El hombre sabio debe amar a su mujer con el juicio, no con la pasión. Que domine el arrebato de la voluptad y no se deje llevar con precipitación hacia la unión sexual» (quoted in Canet 1996: 8). Along these lines, both Prince Juan and Calisto serve as examples of the negative effects of unbridled desire.

As with Prince Juan, excessive erotic activity will become one of Calisto's defining traits. For example, in Act IV Celestina visits Melibea with 
the excuse of selling her some yarn that she has secretly bewitched, and that supposedly will make the young woman fall in love with Calisto. The spell, however, does not seem to work. Celestina then asks Melibea to help the young lover with an alleged toothache for which the only remedy, Celestina swears, is a prayer and «tu cordón que es fama que ha tocados [todas] las reliquias que ay en Roma y Hierusalem» (Severin 1989: 164). The young woman accepts and gives her girdle to Celestina who returns to Calisto in Act vi and explains that, although she has failed in her attempt to arrange a meeting, she is bringing him the most valuable present: "un cordón que ella trae contino ceñido, diziendo que era provechoso para tu mal porque avía tocado muchas reliquias» (Severin 1989: 184). The girdle is charged at once with religious and therapeutic powers that will cure Calisto's heartache, and not only because it has touched venerated relics but also because it has entered in contact with the most sacred body of all: Melibea's.

Unable to contain his impatience, Calisto begs the go-between to show him

aquel santo cordón que tales miembros fue digno de ceñir. Gozarán mis ojos con todos los otros sentidos, pues juntos han sido apassionados. Gozará mi lastimado coraçón, aquel que nunca recibió momento de plazer después que aquella señora conoció. Todos los sentidos le llagaron; todos acorrieron a él con sus esportillas de trabajo; cada uno le lastimó quanto más pudo: los ojos en vella, los oýdos en oýlla, las manos en tocalla. (Severin 1989: 185)

A surprised Celestina asks: "¿Que la has tocado, dizes? Mucho me espantas.» "Entre sueños, digo,» Calisto answers (Severin 1989: 185). After the initial surprise, Celestina tells the young lover: «Da espacio a tu desseo; toma este cordón, que, si yo no me muero, yo te daré a su ama» (Severin 1989: 186). As soon as he receives this intimate object, he transforms it into his confidant, proclaiming: " $\mathrm{O}$ nuevo huésped, o bienaventurado cordón, que tanto poder y merescimiento toviste de ceñir aquel cuerpo que yo no soy digno de servir! ¡O nudos de mi passión, vosotros enlazastes mis desseos! Dezíme si os hallastes presentes en la desconsolada respuesta de aquella a quien vosotros servís y yo adoro" (Severin 1989: 186). Calisto seems to reach the climax of his exagerated linguistic response to the girdle when he exclaims: " $\mathrm{O} \mathrm{mi}$ gloria y ceñidero de aquella angélica criatura, yo te veo y no lo creo!» (Severin 1989: 187).

As this passage illustrates, Calisto redirects his desire for Melibea towards the girdle. It is not even a lock of hair but a piece of clothing that transports the young man into a sort of teenage rapture. Calisto's transference of desire to this garment goes beyond mere contemplation and 
unleashes an exorbitant expression of passion. The girdle becomes an object of excess that demands the production of a hyperbolic response. The young lover is lured by the immediacy of the sweet «reward» embodied in the girdle. In a sort of religious ecstasy, Calisto is so exceedingly overcome by such a hyperbolic performance of desire that even other fictio al characters are in shock. Celestina reacts with surprise and censure: "Cessa ya, señor, esse devanear, que me tienes cansada de escucharte y al cordón, roto de tratarlo» (Severin 1989: 187). For his part, poor Sempronio, who doubts his eyes for the second time witnessing Calisto's excentric conduct in amatory matters, begs him to come to his senses: «Señor, por holgar con el cordón, no querrás gozar de Melibea.» «No afistoles tu llaga cargándola de más desseo;» continues Sempronio, «no es, señor, el solo cordón del que pende tu remedio» (Severin 1989: 188, 189). What is of importance here is that, as illustrated by other characters' reactions, Calisto's exaggerated performance is perceived as extreme and disproportionate, which highlights the hyperbolic nature of the young lover's response to the girdle. In this regard, it is significant to note that Calisto manages to shock Celestina, a woman who works in the sex trade, which is surely an indication of the excess of his response.

Calisto's hyperbolic reaction to the girdle moves from the linguistic to the tactile. He not only interacts with the garment on a visual and linguistic level but also passionately caresses it. This piece of clothing has become an object of devotion in itself, and to treat an object like a subject is to idolize it: it is excessive in dramatically going beyond conventional boundaries and relationships. Treating this piece of cloth as a person rather than as an object suggests that the lover's engagement with it can be viewed as an extravagant expression of love. The girdle becomes an artifact that activates an erotic ritual based on excessive veneration for the beloved, which evokes Calisto's proclamation of faith in Act I, when, renouncing Christian religion, the passionate lover affirms: "¿Yo? Melibeo so, y a Melibea adoro, y en Melibea creo, y a Melibea amo" (Severin 1989: 93). Calisto's obsessive desire for Melibea resembles Prince Juan's in that his behavior, as José Luis Canet points out, «resalta además el incumplimiento de las normas cristianas realizado por Calisto cuya única ansiedad es el goce carnal llegando muchas veces a caer en la herejía al confundir el Sumo Bien o la felicidad con la posesión física de la amada, asimilándose así a la idolatría y por tanto contraviniendo el primer mandamiento de la ley divina» (1997: 54).

At this point, Calisto's performance of passion has exceeded the limits of decorum, even for a veteran of the sex trade such as Celestina, who feels obliged to warn him again about his inappropriate behavior: "deves, señor, cessar tu razón, dar fin a tus luengas querellas, tratar al cordón como cordón porque sepas hazer differencia de habla quando con Melibea te veas; no haga tu lengua yguales la persona y el vestido" (Severin 1989: 
188). It is too late, however, as the girdle has already cast its charms over Calisto who implores Celestina: «O mi señora, mi madre, mi consoladora; déxame gozar con este mensajero de mi gloria». He continues: "O lengua mía, ¿por qué te impides en otras razones, dexando de adorar presente la excellencia de quien por ventura jamás verás en tu poder? $\mathrm{O}$ mis manos, con qué atrevimiento, con quán poco acatamiento tenéys y tratáys la triaca de mi llaga» (Severin 1989: 188). The medieval trope of love as sickness remerges in Calisto's expression of pain, which harks back to Prince Juan and links both lovers within the literary commonplace of amor hereos. Nevertheless, Calisto's erotic trance comes to an end when Celestina leaves taking the girdle with her. The young lover finally gives in, not without a final complaint: " $\mathrm{O}$ desconsolado de mí, la fortuna adversa me sigue junta! Que contigo o con el cordón o con entramos quisiera yo estar acompañado esta noche luenga y escura» (Severin 1989: 191).

Calisto's taste for hyperbolic expression meets with an overly sentimental attitude to shape this extravagant representation of love. However, linguistic exaggeration becomes physical excess in the encounters between the two lovers. In Act XIV, Calisto loses all decorum and consummates his relationship with Melibea in a manner that a consensual relationship is at the least questionable. In this encounter Calisto reveals himself as an excessive lover. His initial prelude in the form of a hyperbolic speech turns into immoderate physicality as suggested by Melibea's words when she complains that "si pensara que tan desmesuradamente te havías de haver conmigo, no fiara mi persona de tu cruel conversación» (Severin 1989: 285). In Act XIX, Melibea clearly sees Calisto's behavior as excessive when, referring to his hands, the young woman urges him: "Mándalas estar sossegadas y dexar su enojoso uso y conversación incomportable.» As Calisto proceeds to undress Melibea, she tries to stop him by saying: "tus deshonestas manos me fatigan quando passan de la razón» (Severin 1989: 323). Melibea's reaction to Calisto's conduct highlights how she perceives his actions as extreme and disproportionate. In the eyes of other characters - Celestina, Sempronio, and MelibeaCalisto is regarded as an intemperate and immoderate individual who breaks expectations in amatory matters. This transgressive behavior is highlighted once again by Melibea when, before committing suicide, she confesses to Pleberio that Calisto "quebrantó con scalas las paredes de tu huerto; quebrantó mi propósito" (Severin 1989: 334); that is, the young man is perceived as an individual who transgresses architectonical, social, moral, and physical boundaries which tinges his actions with an unambiguous air of excess, intemperance, and lack of moderation. These are precisely the aspects that appear in the genre of the humanistic comedy because young lovers just like Prince Juan and Calisto «pierden su razón y libre albedrío al dar rienda suelta a sus pasiones amorosas» (Canet 1996: 9), which establishes a link between the prototype of the 
excessive lover as represented in chronicles, Celestina, and the genre of the humanistic comedy. In the case of Calisto, as with Prince Juan, excess in love (an unmarried Calisto and Melibea enjoy a whole month of illicit love) is punished with death, which serves as a dramatic and didactic device in Celestina.

When compared, then, neither Prince Juan's nor Calisto's love life exhibit the signs that characterize the dignitas hominis, the combination of qualities that extols the spiritual, moral, and rational possibilities of human nature expected from the nobility in $15^{\text {th }}$ and $16^{\text {th }}$ century. As Francisco Rico points out, the group of features that characterized the dignitas hominis range from the qualities of the body to the privileges of the rational soul to prove that «el hombre es superior a los animales por obra de la razón» (1993: 171). Prince Juan's and Calisto's conduct in love shows exactly the opposite: two individuals who are controlled by their passion rather than their intellect. These two characters are not just the protagonists of two interesting erotic stories. Rather, they serve as examples of the destructive power of love, which connects their individual behavior with the common good of society.

In this regard, the distinctive quality of the dignitas hominis is the use of language at the service of the arts in order to "cuidar la salud del cuerpo, de la sociedad y del alma» (Rico 1993: 172). Therefore, as José Luis Canet reminds us regarding the Stoic philosophers, sexual activity was tolerated «cuando sea beneficiosa para la sociedad, pero hay que regular dicha pasión mediante reglas precisas» (1996: 9). We need to remember here that Celestina was written "por la necessidad que nuestra común patria tiene de la presente obra por la muchedumbre de galanes y enamorados mancebos que posee» (Severin 1989, 69). Celestina clearly constructs love as a social disease that could be cured with the reading of the text; a social illness that, when examined through the dual lens of both Calisto's and Prince Juan's inordinate love lives, seems to echo the concerns of Doctor Francisco López de Villalobos regarding the promiscuous life in the Castilian Court. In a letter that he wrote to the bishop of Plasencia in 1509 the royal physician complained that "toda la corte es devorada por el ansia de placeres; en todos sin excepción reina la pasión amorosa, y de todas las edades indistintamente se enseñorea» (Fabié 1886: 233-234. Quoted in Bautista 2008: 44). The doctor continues to criticize all the tournaments and festivities that were celebrated daily in honor of Venus. In her honor "se quema por la noche toda la cera, y se dilapidan todos los bienes heredados o adquiridos por el interés o por la usura, en la pompa de los juegos y en el atavío de criados y de cabalgaduras» (Fabié 1886: 233-234. Quoted in Bautista 2008: 45). This environment of excess and lack of moderation seemed to affect men who: 
pasan todos la noche al raso, sufriendo la lluvia o el frío de las madrugadas, implorando con lágrimas y suspiros el amor de las vírgenes de Citeres. Durante el día todos ejercitan sus fuerzas; a cada paso se dan terribles encuentros, y corren alegres a suntuosos martirios. Con esto borran enteramente de su memoria todo otro cuidado, como la casa, la familia, los negocios, su propia persona y a Dios mismo; que tales son, con otras semejantes, las leyes venéreas, las cuales si bien son penosas e insufribles, al cabo dan con las almas en el infierno. (Fabié 1886: 233-234. Quoted in Bautista 2008: 45)

This decadent environment seems to find its epitome in Prince Juan's legendary passion for Princess Margarite. As heir to the crown and reknowned lover, the physical body of the prince became also an embodiment of the political body of the kingdom. Therefore, it is not surprising that the fatal consequences of Prince Juan's hypersexuality would serve as a cautionary tale for future royal generations. In fact, the prince's legendary love life would emerge with an unexpected exemplary force years later in 1543 as a part of the advice that Charles V passed along to his son Philip II as "la exortaçión que os tengo de dar para después de casado». The emperor warns his son that "convyene mucho que os guardeys y que no os esforçeys a estos principios, de manera que recybyésedes daño en vuestar persona». Therefore, it is not advisable, the emperor counsels his son, to abuse the marital bond "porque demás que eso suele ser dañoso, asy para el creçer del cuerpo como para darle fuerças, muchas vezes pone tanta flaqueza, que estorva a hazer hijos y quita la vida, como lo hizo al prínçipe don Joan, por donde vyne a heredar estos Reynos» (Fernández 1975: 100). The lesson for a future king is clear: if a monarch cannot control his physical urges, how could he reign with a cool head?

From this perspective, Calisto and Prince Juan became the embodiment of lust - excessive physical desire - and its consequences. They certainly qualified as two of those characters from the elegiac and humanistic medieval comedy that, as José Luis Canet reminds us, «no son ni más ni menos que representaciones de carne y hueso de los vicios» (1996: 4). This kind of character, Canet writes, "se caricaturiza al desaparecer la concreción histórico-personal [...], pero sin perder por ello el carácter reprobatorio» (1996: 4). As with Prince Juan a couple of years earlier, in 1499 Calisto also became one of those "galanes ridículos que abandonan toda su virtus por no saber poner freno a su pasión amorosa se convierten en los verdaderos modelos de la comedia posterior» (Canet 1997: 59). Both lovers served as examples of behavior in which the intellect is subjugated to the passions to such an extent that they became two puppets with a 
hyperbolic conduct beyond the limit of social decorum: two exemplary lovers that served in fact as antimodels.

\section{Dying of Love: Exemplarity and Didacticism}

In $15^{\text {th }}$ Century Iberia death vies only with love for a place of pre-eminence. Neither Prince Juan nor Calisto would be an exception to this rule. In fact, according to the chroniclers, Prince Juan's doctors must have been right because while celebrating his arrival in Salamanca in October 1497 the prince's lack of sexual moderation proved so debilitating as to provoke his untimely demise at age 19.

The prince's hyperbolic sexuality had given wings to the legend that his sexual ardor was so great that it killed him. As we have seen, Mártir de Anglería's accounts echo this point when he openly states that Prince Juan died due to the physical exhaustion provoked by the excessive sexual activity with his wife. This cause of death is corroborated by Andrés Bernáldez, chronicler of the Catholic Kings, who reports that «estando en el hervor de su plazer, llegó el príncipe don Juan rendido por sus ciertas jornadas al cabo de su peregrinación que vino a andar en este mísero mundo» (Gómez Moreno and Mata Carriazo 1962: 378). Both chroniclers, then, agreed that unbridled passion sent the prince to an early grave: the Italian humanist suggests a gradual slow process of wearing down, whereas the Castilian chronicler insinuates a collapse during intercourse.

Several ballads composed at the end of the $15^{\text {th }}$ Century recreate the prince's deathbed and confirm the diagnosis of love as a terminal disease: "Malo está don Juan de amores, / muy malo está en su cama» (Catalán 1998: 69). Another ballad refers to the prince suffering "sudor de vida» which, as Paloma Díaz explains, it is significant as «los sudores eran el remedio específico para las enfermedades venereas» (1993: footnote 18, 177). Other accounts contested the love diagnosis and suggested that despite the excessive celebration of the marital bond, the prince's death was provoked by chronic gastric illness complicated by smallpox as we read in one of the royal account books when we learn about «una ropa de grama que tiene cinco varas que se fizo en Medina del Campo estando su alteza de las viruelas» (Azcona 1992: 235), or high fever: «Malo está de calentura, que otro mal no se le halla» (Catalán 1998: 46). Other sources point at death by accident, "El señor Príncipe don Juan está malo en Salamanca, / que cayó de su caballo a las puertas de su amada, / por cortar un ramo verde y ponerlo en su ventana" (Catalán 1998: 69), or even poisoning by the judeoconverso Doctor Parra (Alcalá and Sanz 1999: 182), who «dicen que es gran dotor, gran dotor que adivinaba / Trae solimán en el 
dedo, en la boca se lo echara: / «Tres horas tiene de vida, la media ya está pasada» (Castro 1929: 169). ${ }^{9}$

Of all these possible causes for the prince's death, excessive sexual activity served as a more powerful didactic tool than chronic gastritis or smallpox, and of course juicier material for the writers of the time who constructed the public image of Prince Juan as a puppet in the hands of love. However, the abundant production of consolatory literature around the prince's demise created a counter-discourse by crafting a narrative of the heir as an ideal Christian at death. After having being portrayed as a negative example of an excessive lover, now it was the time to fabricate a good death. The elegiac literature around Prince Juan worked against the weight of the gossip around his love life by counteracting his image of a wild lover with that other image of a pious Christian who died a good death. ${ }^{10}$

Dying well was an opportunity to redeem oneself, thus in a way scripting a better future in Heaven by tidying up messes made in the past. With this purpose, during the $15^{\text {th }}$ Century the Church began to use confessionals to emphasize the existence of an individual consciousness. The goal of these practical manuals was to teach clerics the art of confession and take advantage of absolution as a strategy to harvest souls. Confessionals also focused on penitents by teaching them how to conduct a proper self-examination prior to the administration of the rite. As Francisco

9.- According to Diego Catalán, «la variante acusatoria debió de surgir en algún período de fuerte anti-semitismo, cuando la profesión médica seguía estando aún dominada por 'confesos', por cristianos nuevos. Pudo muy bien tener su origen en la etapa inicial de la propagación del romance noticiero (1998: 99). For more on the Jewish origins of Doctor Parra see pages 99-107. For a detailed overview regarding the causes of Prince Juan's demise see Tarsicio Azcona (1992), «El príncipe don Juan, heredero de los Reyes Católicos en el V Centenario de su nacimiento (1478-1497)», Cuadernos de Investigación Histórica, pp. 219-243; and Ángel Alcalá y Jacobo Sanz (1999), Vida y muerte del príncipe don Juan, Valladolid: Consejería de Educación y Cultura de la Junta de Castilla y León, pp. 179-186.

10.- The consolatory literature that emerged from Prince Juan's demise was indeed abundant. As Giuseppe Mazzocchi points out, «en su conjunto todos los textos que se compusieron [...] nos dan una pauta casi exhaustiva de los géneros literarios más practicados durante el reinado de los Reyes Católicos, de la poesía narrativa en latín al romance popular, del tratado en prosa a la carta consolatoria, de los géneros líricos menores a poemas elegíacos de mayor extensión» (1988: 93). For an overview of this literature, see Tomás González, José Miguel Baños Baños, and Pilar Saquero Suárez-Somonte (2006), El humanismo cristiano en la Corte de los Reyes Católicos: las consolatorias latinas a la muerte del Príncipe Juan, Madrid, Ediciones Clásicas; Ángel Alcalá and Jacobo Sanz (1999), Vida y muerte del príncipe don Juan, Valladolid, Consejería de Educación y Cultura de la Junta de Castilla y León; José Camón Aznar (1963), Sobre la muerte del príncipe don Juan, Madrid, Real Academia de la Historia; Miguel Ángel Pérez Priego (1992), «Historia y literatura en torno al príncipe D. Juan: La representación sobre el poder del amor de Juan del Encina", in Historias y ficciones: Coloquio sobre la literatura del siglo XV, Valencia, Universidad de Valencia, pp. 337-49; Enrique San Miguel Pérez (1998), «España y su príncipe en la poesía de Juan del Enzina» in La figura del principe de Asturias en la corona española, Madrid, Editorial Dykinson, pp. 147-164; Jacobo Sanz Hermida (1995), "Cien mil esperanças allí se anegaron" in Medioevo y literatura: Actas del V Congreso de la Asociación Hispánica de Literatura Medieval, Vol. 4, Granada, Universidad de Granada, pp. 307-19. 
Gago Jover reminds us, «el momento de la muerte y el de la confesión tienen en común la necesidad del individuo de reconocerse como tal y de afrontar sin tapujos la responsabilidad consigo mismo" (1999: 43). Within the model of a feudal society that did not permit individuality in life, this self-examination of one's own consciousness prior to death allowed the dying the chance to shape these last moments. This process of introspection allowed for three strategies that had a crucial influence over the destiny of the soul. First, confession became an act of responsibility which demanded the compliance with rules that permitted the individual some autonomy over the group. In fact, this sacrament led the list of steps to be followed in the Ars Moriendi in order to achieve a good death: "Primeramente, que con grand contrición de sus pecados faga [el moribundo] entera confesión, e dende resciba todos los otros sacramentos necessarios con grand reverencia e devoción» (Gago 1999: 84).

Along with the need for confession, a second theme that recurs throughout the Ars Moriendi was the fear of dying unexpectedly: "muy expediente e conveniente cosa es que cualquier que desea ser salvo [...] piense en su coraçón muchas vezes en la enfermedad postremera de que ha de morir» [...] "Mas muy pocas vezes alguno se dispone bien quando la muerte le toma súbitamente; porque cada uno piensa de vivir muy largamente, non creyendo que tan aína aya de morir» (Gago 1999: 82). ${ }^{11}$

A third element that was emphasized by the Church at the moment of death included the paperwork essential to assure a dying person's salvation: the last will and testament. This document was an important step towards the salvation of the soul as it allowed the dying to customize the practical aspects of their death: the choice of the burial place, rituals to be performed at the funeral, what prayers and ceremonies should be conducted by whom and how, and the commission of masses to both perpetuate their memory and pray for their soul. The last will served as a chance to right wrongs, pay debts and perform charitable acts: a document that served as a conciliatory tool between the dying, who had the chance to construct themselves as good Christians, and those around them. ${ }^{12}$

11.- This notion had become a commonplace throughout the literature of the Middle Ages in general and in the 15th Century in particular: "Y pues somos inciertos quándo havemos de ser llamados,» Pleberio advises Alisa in Celestina, «viendo tan ciertas señales, devemos echar nuestras barvas en remojo y aparejar nuestros fardeles para andar este forçoso camino; no nos tome improvisos ni de salto aquella cruel boz de la muerte; ordenemos nuestras ánimas con tiempo; que más vale prevenir que ser prevenidos. Demos nuestra hazienda a dulce sucessor» (Severin 1989: 301-302).

12.- Scholars are divided in regards to determining the importance of the last will and testament for the individual. According to Philippe Ariès this document had both a pragmatic and moral function: «the disposition of one's property, not only ad pias causas but among one's heirs, became a duty, a matter of conscience» (2000: 196). Adeline Rucquoi argues that last wills and testaments were a formulaic textual corpus related to a specific literary genre rather than to the individual needs of the dying (1986: 58-64). Jaume Aurell Cardona, on 
As portrayed in the consolatory literature of the time, the prince certainly had a most exemplary demise. The voices that filter popular sentiment through these works largely concur that the prince fulfilled all the requirements for a good death. They all insist on the fact that he confessed, said his good-byes, and wrote his will, which allowed him to both rewrite his past and script a pious future both in the minds of the public and in the afterlife.

A couple of days before Prince Juan's demise, Fray Diego de Deza - the heir's personal caretaker-, wrote to the kings to let them know that the end was near. He asked them to assist their son in his final moments by helping him with the necessary requirements to save his soul, among them being the writing of his last will and testament (Pérez-Bustamante and Calderón Ortega 1999: 306-07). Fray Diego also insisted that the kings should also be next to the prince because, according to the Ars Moriendi, it is in these final moments that the devil intervenes "temptando al ombre en postremera enfermedad con muy grandes temptaciones» (Gago 1999: 82). In his Tratado del fallesçimiento del muy inclito señor don Juan, Alonso Ortiz confirms this premise because even at this crucial moment Princess Margarite was still an obsessive presence in Prince Juan's mind as he appears to be lusting for her in agony: «Requiría a menudo, demandando consejo, al confessor para alimpiar las manzillas de su consçiençia [...] y commo la recordaçión de su esposa tocasse muchas vezes su ánima y con su deseo su ánima se enflamasse, boluióse al padre espiritual diziendo: $¡ O$ padre, enflaquesçe mi ánima con el deseo de mi muger, pregunto te si es digno de culpa este amor de mi propia muger!» (Sanz 2000: 58). ${ }^{13}$ According to Ortiz, at that key moment the dying prince "començó examinar con diligencia los secretos de su consçiençia y demandar las armas

the contrary, notes that the last will and testament allowed the expression of emotions and individual wishes. He argues that due to the dissemination of Romance languages and their status as legal languages «los testamentos dejan de ser una mera formalidad jurídica en orden a solemnizar la transmisión de los bienes materiales del difunto para entrar en el universo de la justificación de la actuación de toda una vida» (2002: 90-91). For more on last wills and testaments see E. Portela and M. C. Pallarés (1986), «Muerte y sociedad en la Castilla medieval (ss. XII-XIV)", en La Idea y el sentimiento de la muerte en la historia y en el arte de la Edad Media (I), Santiago de Compostela: Universidad de Santiago de Compostela, pp. 51-66; María del Mar García Guzmán y Juan Abellán Pérez (1997), La religiosidad de los jerezanos según sus testamentos: (siglo XV), Cádiz: Agrija Ediciones; and María del Carmen Carlé (1993), Una sociedad del siglo XV: los castellanos en sus testamentos, Buenos Aires: Universidad Católica Argentina.

13.- According to Diego Catalán, passages like this indicate that, despite its rhetorical artistry, Alonso Ortiz's consolatory treatise is far from being an account of the exemplary death of Prince Juan, which «nos obliga, por lo tanto, a considerar menos sorprendente la conversación que incluye la singular versión romancística de Soto de Sajambre (León). En ella, la reina subraya apesadumbrada: 'Bastante le dejas, hijo, para tan poco gozarla', contraponiendo los dones que el príncipe quiere que le respeten a su esposa, con la brevedad de su matrimonio; a lo que don Juan contesta: 'Bastante la gocé, madre, que de mí queda preñada', tomando el verbo "gozar» en su tercera acepción del Diccionario de la Academia» (1998; 66-67). 
espirituales, asý como el que avía de pelear con enemigo cruel, y todo se recomienda fielmente a la divina voluntad» (Sanz 2000: 56).

Prince Juan's own words at this crucial moment also reflect his anxiety about the collective concern of dying unexpectedly without confession: «nos conuyene velar porque cuando vinyere aquel postrimero dia, el qual ny su hora saber podemos, no nos halle dormiendo, mas nos halle ya aver proveydo a la salud de nuestras animas por confesion e contricion e satisfaçion e disposiçion de los bienes temporales, mayormente syendo nuestros dias como son breues e se pasan como sombra» (Escudero 1870: 234). A good death had become then an act of responsibility that required self-examination and a pro-active attitude in order to avoid a bad death.

Prince Juan had a say into how he wanted to die, thus choosing to recast himself as a model Christian and sole protagonist of an exemplary, conventional, and pious death. Ortiz's account portrays the prince's deathbed scene as emerging from the Ars moriendi in which Moriens lies in his bed in the company of family and clergy. At the moment of death, Prince Juan was surrounded by his father King Ferdinand, his personal caretaker Fray Diego de Deza, his tutor Sancho de Castilla, his secretary Gaspar de Gricio, and other members of the court and the clergy. Exhibiting a stoic attitude, the young heir took such ownership over his own death that Mártir de Anglería, an eyewitness to the scene, notes that "con maravillosa exaltación de alma dirigía la palabra al padre, que estaba sorprendido de la senil entereza del joven hijo» (López de Toro 1953: 346). The prince's demise, then, conformed to the model of good death advocated by the Church.

By carefully orchestrating his final days, Prince Juan had the opportunity to demonstrate the measure and control over death that he lacked in the arms of love. He was then paradoxically both an example and a counter-example of the ideal lover - as he threw himself unconditionally and constantly to the pursuit of pleasure - and the ideal Christian at dying. He gave his heart to passion but saved his soul for God. To the contemporary popular mind the prince's story served as an example of the tragedy of a consummate lover. However, as emphasized by most accounts, he managed to die well by means of three key actions: self-examination, confession, and the writing of the last will and testament.

As has been studied in detailed by Celestina scholars, as constructed by Rojas, Calisto's death was far from glorious. In fact, the portrayal of his death provides a counterpoint to Prince Juan's demise. In order to emphasize the destructive power of love, Rojas does not give Calisto the chance to redeem himself through self-examination, confession, or the writing of his last will and testament. His death, full of tragic and parodic elements, is caused by accident when, exhibiting an uncharacteristic drive to perform an apparently honorable action, Calisto runs to help Tristán and Sosia and dies when he falls from the ladder he had used to access 
Melibea's garden. However, «there is no heroism here, either, but rather one more show of bravery where there is no peril, cowardice disguised as heroism yet again» (Rutherford 2001: 173). Calisto, then, becomes a parody of himself, a disreputable individual whose apparently honorable action transforms him into a caricature. The tragic effect of Calisto's death turns into comedy because, as a forerunner of the literary aesthetics of $16^{\text {th }}$ century, "only deaths of low-life characters could be funny: then, again, these lovers 'lascivia rústica y grosera' has dragged them down to the level of low-life characters as has Calisto's cowardice» (Rutherford 2001: 175).

In order to make an example of Calisto's death, the collective fear of dying unexpectedly without confession is highlighted when the young lover exclaims as he falls: "¡¡ válame Santa María, muerto soy! ¡Confessión!'.» Tristán, being completely aware of the consequences of his master's awful death, confirms Calisto's bad death by saying " $; O$ triste muerte $[y]$ sin confessión!'» which he emphasizes again when he asks Lucrecia to convey the tragic news to Melibea: «su cabeça está en tres partes. Sin confissión pereció» (Severin 1989: 326-328). Later on, Melibea herself will insist on this fear when she relates Calisto's death to her father: "Cortaron las hadas sus hilos; cortáronle sin confessión su vida" (Severin 1989: 334). These words take the reader back to the end of Act XII in which Sempronio and Pármeno kill Celestina. As a dramatic device to emphasize Celestina's bad death, Rojas chooses as her last words the following desperate cry: "'i Ay, que me ha muerto, ay, ay, confessión, confessión!'» (Severin 1989: 274). The didactic message that emerges from these two deaths could not be clearer: dying unexpectedly was, indeed, the worst punishment of all as it entailed the lack of confession, which in the case of Calisto and Celestina led to the condemnation of their souls. ${ }^{14}$

From this perspective, in contrast to Prince Juan, Calisto becomes one of those characters «peores» and «más viciosos» portrayed in the genre of the humanistic comedy whose authors, just like Rojas, «escogen a prototipos que transgreden cada una de las normativas en vigor, tanto cristianas como éticas» (Canet 1996: 6). In this case, Rojas created an exemplary antihero representative of the miseria hominis, «al peor de los 'peores,' a aquél que contraviene todas las normas conscientemente, aquél que rompe con los preceptos establecidos bajo una aparente impunidad» (Canet 1996: 14). Calisto, then, serves as an example of a bad death that, when contrasted to Prince Juan's demise, reinforces the ecclesiastical guidelines prescribed by confessionals, penitentials, and the Ars moriendi.

14.- For more information on this topic see Alan Deyermond (1984), "¡Muerto soy! ¡Confesión!' 'Celestina' y el arrepentimiento a última hora", De los romances-villancico a la poesía de Claudio Rodríguez: 22 ensayos sobre las literaturas española e hispanoamericana en homenaje a Gustav Siebenmann, ed. José Manuel López de Abadía and Augusta López Bernasocchi, Madrid: J. Esteban, pp. 129-140; and Jean Delumeau (1992), La Confesión y el perdón. Las dificultades de la confesión, siglos XIII a XVIII, Madrid, Alianza Editorial. 
In regards to the deaths of Prince Juan and Calisto, there are several points of textual connection between Celestina and the consolatory literature surrounding the prince's demise. These relationships indicate that not only was Rojas familiar with the heir's life and death as an event of international political dimensions, but also that he found inspiration in the literary production emerging from the prince's demise, more specifically in the works that Juan del Encina - one of Rojas' classmates in Salamanca- devoted to Prince Juan. ${ }^{15}$ It should not be surprising, then, that the literary tracks of these specific texts reappear in Rojas' depiction of Calisto as a character inspired by Prince Juan.

15.- This poet had a special connection with Prince Juan. Del Encina dedicated to him his translation of the Bucólicas by Vrigilio (1496) and El arte de poesía castellana (1496). He also wrote Representación de Amor, a play performed for the prince on his visit to Salamanca in 1497, and whose main topic was the power of Love, «sin duda, acorde con la fama que ya corría de la intensa pasión que vivían los príncipes» (Pérez Priego 2007: 1236). At the prince's death, Del Encina composed a ballad ("Triste España sin ventura»), a villlancico ("A tal pérdida tan triste»), and Tragedia trobada (1497), in which the poet narrates the events that happened from Prince Juan's birth to his demise, addresses the city of Salamanca as the unfortunate place in which the prince's death occurred, and writes a consolation.

As has been already studied by several scholars, the following passages from Celestina can be traced back to Juan del Encina's "A la dolorosa muerte del Príncipe don Juan...».

1. «Si passa por los perros aquello suena su ladrido;» (Act I, 108)

2. «... Medea, la nigromantesa.» (Act xx, 332)

3. "Que si aquella severidad y paciencia de Paulo Emilio me viniere a consolar...» (Act xXI, 339)

4. «... que fuimos semejantes en pérdida aquel Anaxágoras y yo ...» (Act XXI, 340)

5. «... Pericles, capitán ateniense ...» (Act XXI, 340)

The following passages from Celestina seem to have been inspired by "Al muy esclarecido y bien aventurado Príncipe don Juan...», Cancionero de Juan del Encina (1496):

1. "Y como mirase su primor, su sotil artificio, su fuerte y claro metal, su modo y manera de lavor, su estilo elegante ...» («El autor a un su amigo,»69).

2. "... quiso celar e encubrir su nombre, no me culpéys si en el fin baxo que lo pongo...» («El autor a un su amigo,» 69).

3. «... bolved ya las riendas por que n’os perdáis ...» («El autor, escusándose de su yerro..., 75).

4. «Pero como mi pobre saber no baste a más de roer sus secas cortezas de los dichos...» («Prólogo,» 77).

5. «...de manera que acordé, aunque contra mi voluntad, meter segunda vez la pluma en tan estraña lavor y tan agena de mi facultad, hurtando algunos ratos a mi principal estudio, con otras horas destinadas para recreación, puesto que no han de faltar nuevos detractores a la nueva adición» («Prólogo,»81).

6. «tórnese lloro vuestra gloria, trabajo vuestro descanso;» (Act XV, 298)

7. «...por que no me secasses sin tiempo esta flor que este día echaste de tu poder.» (Act XXI, 338)

For these references I am using Fernando Cantalapiedra Erostarbe (2000), Tragicomedia de Calisto y Melibea. v Centenario: 1499-1999, 3 volumes, Reichenberger, Kassel. For an examination of the presence of Del Encina's work in Celestina, see Castro Guisasola's study, pages 180-182. For an overview on Juan del Encina's works on Prince Juan, see Enrique San Miguel Pérez (1998), «España y su príncipe en la poesía de Juan del Enzina», in La figura del príncipe de Asturias en la corona española, Madrid, Editorial Dykinson, pp. 147-164. 
In Act XIX we find a connection of particular relevance that situates Prince Juan as a source for Rojas. Erna Ruth Berndt perceives the echo of Diego Ramírez de Villaescusa's Diálogo a la muerte del principe don Juan (1498) in Melibea's expression of pain and suicide: «Mi bien y plazer todo es ydo en humo; mi alegría es perdida; consumióse mi gloria. [...] Rezando llevan con responso mi bien todo; muerta llevan mi alegría. No es tiempo de yo bivir» (Severin 1989: 327-328) (Berndt 1963: footnote 50, 112-114). Likewise, Miguel Marciales' reading of Melibea's self-accusatory words,

Bien ves y oyes este triste y doloroso sentimiento que toda la cibdad haze. Bien oyes este clamor de campanas, este alarido de gentes, este aullido de canes, este [grande] strépito de armas. De todo esto fue yo [la] causa. Yo cobrí de luto y xergas en este día quasi la mayor parte de la cibdadana cavallería; yo dexé [hoy] muchos sirvientes descubiertos de señor; yo quité muchas raciones y limosnas a pobres y envergonçantes. Yo fui ocasión que los muertos toviessen compañía del más acabado hombre que en gracias nació. Yo quité a los vivos el dechado de gentileza, de invenciones galanas, de atavíos y bordaduras, de habla, de andar, de cortesía, de virtud. Yo fui causa que la tierra goze sin tiempo el más noble cuerpo y más fresca juventud que al mundo era en nuestra edad criada. (Severin 1989: 333)

indicates that «aparentemente Melibea flota en un mar de exageración retórica y resulta la causa del más lamentable desastre ocurrido en aquella ciudad. Pero es que realmente,» Marciales explains, "lo que Rojas [...] tiene en mientes no es la muerte de Calisto, el saltaparedes, sino la dolorosa muerte del príncipe don Juan, de gloriosa memoria, el príncipe que murió de amor» (Marciales 1985: footnote Xx.23, 258). ${ }^{16}$

The hyperbolic sense of mourning that emerges from Melibea's words evokes the exaggeration that characterized the expressions of mourning for Prince Juan. In fact, «jamás se vieron en España expresiones de dolor tan intensas, paradójicamente no porque el príncipe hubiera hecho grandes hazañas en vida, sino por la esperanza mesiánica que representaba y el cambio de dinastía a que muerte obligaba» (Sánchez-Molero 1999: 873). A contemporary source relates that «Por espacio de quarenta días se enlutaron todos los Grandes, Caballeros, vasallos y Embaxadores de Reyes; en todas las puertas de las Ciudades estuvieron puestas vanderas negras, celebrando pompas fúnebres e señal de sentimiento, y tristeza $[\ldots]$ grandes y pequeños se vistieron de xerga blanca, que fue la

16.- On the contrary, Julio Rodríguez Puértolas points out that this invocation is as interesting as it is dubious (1996: footnote 22, 296). 
última vez que se usó esta manera de luto en Castilla» (Gómez Imaz 1890: 30). Mourning rituals for the prince's demise were so exaggerated that in 1502 the Catholic Kings passed the Pragmática de luto y cera. The goal of this text was to restrict the ostentation that Castilians exhibited in funerary ceremonies because «la mucha desorden e gastos superfluos é demasiados que muchos de nuestros súbditos é naturales hazen en las ropas de luto que toman por los difuntos é en la cera que se echa a perder en los enterramientos é obsequias é honras dellos que dios nuestro señor no es servido ni su iglesia aprovechada: é los herederos de los defuntos son danificado » (Gómez Imaz 1890: 31). ${ }^{17}$

Reading Melibea's words in conjunction with these passages, these expressions of pain are similar to each other. Rojas himself probably witnessed first-hand the exaggerated manifestations of mourning for Prince Juan in Salamanca which, as happened with his contemporaries, would have left a mark in his mind thus allowing for the possibility of bringing together Prince Juan and Calisto in his creative process. The legendary hyperbolic passion of the young heir and the extreme expressions of mourning that Castilians exhibited to honor his demise constructed the prince as an example that not only was a part of the fabric of the quotidian life of Castilians but also become integrated in the collective imaginary of the time as a popular icon and political model. ${ }^{18}$ The widely-known circumstances that converged in Prince Juan's life and death allowed for a contemporary archetype familiar to Rojas as he created Calisto.

Furthermore, as José Luis Canet points out «los humanistas en su afán de imitar la vida, escogen personajes jóvenes y cultos [...] como antihéroes. Pero para la configuración caricaturesca bien pudieron basarse en los penitenciales, los decretales y libros sinodales [...] acumulando así en uno o varios tipos sociales todos los pecados (sobre todo los referidos a la sexualidad), mostrándonos a los 'peores,' a los que no debemos imitar» (1996: 18). Read together, Calisto can be seen as a parodic and «improved» didactic version of Prince Juan as Rojas increases his efficacy

17.- In regards to the amount of wax, we know that in Prince Juan's funeral rites such a quantity of wax was burned that it was necessary to bring it from other cities such as Segovia, Medina del Campo, Arévalo y Santa María de Nieva because the city of Salamanca run out of it. As a result, Gabriel Maura Gamazo reminds us, "se dificultó de sobremanera no sólo el alumbrado doméstico en la comarca, sino la renovación del vestuarios de sus moradores, agotó la Corte en los mercados próximos las existencias de telas idóneas [...] y las llamadas 'piezas de luto'» (2000: 206).

18.- For an example of what a strong presence the memory of Prince Juan exerted in the collective imaginary of 16th Century Spain see José Luis Gonzalo Sánchez-Molero (1999), «El Príncipe Juan de Trastámara, un exemplum vitae para Felipe II en su infancia y juventud», Hispania, 59.3, no. 203, pp. 871-896. This scholar presents a very interesting argument in regards to the ways in which Prince Juan was instrumentalized between 1527 and 1548, a period in which the future Phillip II went through a process of castilianization through models, archetypes, and social images linked to Prince Juan. 
as an example by preventing Calisto from achieving salvation. In amatory matters they both fit perfectly the humanist tendency of creating anti-exemplary models using young educated individuals. As we read in «El autor a un su amigo,» Celestina was intended as a defensive weapon for the youth to fight the tormenting fires of love. This manifestiation of intentions regarding the goal of the text evokes «la función del humanista $y$ de los docentes es educar a la juventud, y es en esta época donde reinan las pasiones, y donde con mayor fuerza se sienten los apetitos sensuales» (Canet 1997: 53). Both Prince Juan and Calisto conform this model. However, when examined together from the point of view of creating a didactic example, in Celestina, being an excessive lover precludes the opportunity of salvation. With this goal in mind, what could have been a better didactic example for the young than the parodic narrative of an excessive lover like Calisto who engages in an illicit love as he transgresses all the social and moral rules, and then turning that parody into tragedy by having the young lover being inevitably condemned?

Both Prince Juan and Calisto share the dubious honor of being exemplary lovers: by transgressing rules they served as anti-models of an excessive conduct. In death, however, both lovers were on the opposite sides of the same coin: whereas Prince Juan died as the paragon of a good Christian, Calisto died as an example of the worst death of all, unexpected and without confession.

\section{Conclusions}

In light of all the above, could have Prince Juan served as an antecedent that gave shape to Calisto? As represented in the literary accounts of the time, could have the prince's excessive love life been used as a source for Calisto's depiction as "loco enamorado"?

As Elena Rojas Mayer points out, the meanings of a text emerge from the combination of contextual elements that surface "a través de las circunstancias exteriores al texto, las que lo rodean e influyen en su constitución muchas veces por información explícita del autor o a través de textos suministrados por otros. Pueden ser factores de distinto tipo: históricos, geográficos, sociales, políticos, culturales, religiosos, psicológicos» (2001: 582). Among the events that took place between 1497 and 1499 that may have influenced Rojas' creative process, Prince Juan's demise clearly stands out as a significant one.

As Stephen Gilman suggests in his study La España de Fernando de Rojas, we know that Rojas probably lived in Salamanca between 1494 and 1502. We also know that "algunas partes de La Celestina fueron escritas en Salamanca durante las vacaciones de Pascua de 1497 ó 1498» (Gilman 1978: 270). Gilman's study also reveals that the confessor to the prince, 
Diego de Deza, and the royal doctor Alonso de la Parra who assisted the young heir at his death, were among other distinguished humanist professors during Rojas' time in Salamanca. Likewise, another of Rojas' professors, Rodrigo Basurto "tenía fama de haber predicho la muerte repentina del príncipe Juan durante una visita a Salamanca en 1497» (Gilman 1978: 273). As Gilman suggests, Rojas «pudo haber sido testigo de semejante acontecimiento" (1978: 303-304). Being in Salamanca at the time of the prince's death and forming part of the literary circles of the time, Rojas may well have experienced first-hand the effects of the prince's demise. The prince's death and his legendary love story, then, could have left their mark on Rojas as, at the time of the composition of Celestina, the aura of Prince Juan's story was very much «in the air,» using Jacques Barzun's concept (2000: 49).

It is not infrequent for literary sources or historical events to influence works of literature without the need to explicitly identify these allusions. The familiarity with certain references that are an integral part of the collective unconsciousness of a given culture facilitates their infiltration into a specific literary text, which makes it unnecessary to be explicit. In fact, the collective literary imaginary of a culture is composed of a selection of sources, references, and allusions that are sometimes elusive as their presence is not always visible in the text itself. ${ }^{19}$ Sometimes these implied allusions are like threads that the audience needs to recognize and weave together to reconstruct the intricate tapestry of meanings in a text because, as Paul Strohm reminds us, texts are never "fully candid and articulate about themselves and their own prehistories and the circumstances of their composition» (2000: xii). For example, as Francisco Márquez Villanueva points out in regard to the influences of the Arab world on Celestina, "la historia social y de las mentalidades se inserta de un modo espontáneo en la historia literaria, porque en gran parte se nutre de ésta y termina actuado a su vez sobre sí misma» (1993: 11-12). From this perspective, the presence of the Arab tradition in Celestina has not always translated into exact quotes of specific passages but rather into the portrayal of social realities as a reflection of the collective unconscious imaginary highlighting the fact that works like Celestina "no se conciben sin la entrada en juego de toda una civilización, que deja en ellas un profundo y fiel testimonio de sí misma» (Márquez illanueva 1993: 9).

This kind of association between a text and its sources can be applied to Celestina and Prince Juan. As contemporary chroniclers and ballads show, the young heir was an integral part of the Castilian collective imaginary, which from an artistic perspective may well be reason enough for Ro-

19.- For example, as Stephen Gilman has indicated, Rojas owned a copy of one of his classmates' works, Luis de Lucena's Repetición de amores e arte de axedrez. Rojas could have used his source to «entretenerse con las posibles combinaciones de finales de partida que Sempronio había recomendado a Calisto para distraerse del tormento amoroso" (1978: 414). 
jas not to feel the need to make an explicit connection between Calisto and Prince Juan. Indeed, the wide range of written texts that circulated widely in Salamanca shared the literary space of this city with a fluid oral tradition of ballads, romances, and Cancionero poetry (which Rojas makes his characters recite) ${ }^{20}$ a highly intertextual body of literature which gave shape to the Castilian collective imaginary.

Several conclusions emerge from the comparison between Prince Juan and Calisto that this article proposes. These two literary representation of exorbitant love draw attention to excess as a concept that calls for a dynamic model of pleasure which transcends and blurs boundaries between health and disease, and the moderation and lack of control that skate to the brink of love. Both Prince Juan and Calisto embarked on an exemplary and relentless pursuit for extreme bodily sensations in disregard of social codes and boundaries. They both paid with their lives their extreme pursuit of pleasure, which served as a way to exemplify the dangers of loving in excess. These two legendary young men are an integral part of that literary lineage of lovers "modelos de antimodelos,» that as José Luis Canet reminds us, «llegará hasta el Romanticismo» (Canet 1997: 59). As constructed by Rojas and other contemporary authors who recreated Prince Juan's life and death, excess became a negotiated concept simultaneously serving a literary use and didactic function in order to teach how to love and to die well.

Both Prince Juan and Calisto fell victim to the effects of too much of a good thing. The literary imagination of late medieval Iberia crafted two exemplary lovers, epitomes of the figure of the 'Fall of Princes' along with the whims of Fortune and of the destructive effects of love, who share the excess of their actions in love but are distinguished from each other in death: Prince Juan was redeemed by the way he died, but the sudden nature of Calisto's demise, with no time for confession, precluded an epilogue of salvation. They both died but in the case of Prince Juan, the literary reception of his story emphasized the option of a good death, whereas in Celestina excess manifests the great danger to society when moderation is lost and extravagance takes control. Both Prince Juan and Calisto gave themselves to relentless pursuit of extreme pleasure: they were good lovers to the mortal detriment of that very vehicle and instrument of pleasure. As death is the price of inordinate passion, excess becomes a signifying practice activated by the intersection of a taste for extravagance in love attitudes that stem from courtly love literature and the didactic trend promoted by the Ars moriendi in late medieval Iberia.

20.- In fact, the Cancionero poetry serves as a model for Calisto's speeches on love. For more on this aspect, see Antony van Beysterveldt (1982), Amadís-Esplandián-Calisto. Historia de un linaje adulterado, Madrid, José Porrúa Turanzas Ediciones, pp. 125-153; and Francisco Lobera Serrano (2014), "La Poesía de Cancionero en La Celestina: 'Oh, Hideputa el trovador'», Revista de Poética Medieval 28, pp. 225-243. 
Lastly, the combination of literary and historical sources that come into play in comparing Prince Juan and Calisto also illuminates the ways in which history and fiction mingled in the Iberian late Middle Ages as two discourses that «se alimentan o benefician mutuamente con el objetivo de duplicar su eficacia e interés, aprovechando la virtualidad legitimadora de la historia y la capacidad estética de la ficción» (Bautista 2004: 28). ${ }^{21}$ In this regard, the depiction of such excessive lovers as Calisto and Prince Juan confirms the intrahistory of the Castilian court as an institution «devorada por el ansia de placeres» as portrayed by Doctor Francisco López Villalobos in his Sumario de Medicina. Given the proximity in time of the prince's demise (1497) to the first editions of Celestina (1499), the geographical immediacy (Salamanca), and the fact that the prince's story was immediately and broadly disseminated in the form of popular and learned literature, ${ }^{22}$ it seems unnecessary for Rojas to make an explicit link between Prince Juan and Calisto for his audience. His contemporaries would have recognized the subtext of the erotic narrative of Prince Juan because texts work by "accommodating full renderings of their immediate cultural circumstances and other less intelligible impulses» (Strohm 2000: 212). The obsessive erotic passion of Calisto for Melibea could have evoked the tragic desire of Prince Juan for Princess Margarite in the mind of Rojas' audience. Similarly, the audience of ballads devoted to Prince Juan and Celestina would have found common points between historical facts and literary fiction. As Henk de Vries points out, Calisto and Melibea are twenty-three years old. Prince Juan, had he not died, and Princess Margarite "would have been Calisto's and Melibea's age in 1500, when the first edition of this bitter Comedia [...] was published in Toledo," a possible allusion that "contemporary readers would not have failed to see» (1999:17). In this way, fiction is capable of negotiating the

21.- For the combination of historical and fictional discourses surrounding Prince Juan, see Clara Marías Martínez (2015), «Historia y ficción en el romance de la 'Muerte del príncipe don Juan': De la princesa Margarita a las viudas de la tradición oral» in "Estorias», aventuras y poesía en la Edad Media, ed. Marta Haro Cortés, 2 Volumes, pp. 643-669.

22.- According to Arovich de Bogado «las primeras versiones de 'La Muerte del Príncipe Don Juan' se ubican hacia 1497» (1992: 270). More specifically, the ballads that recreated the prince's demise must have been composed before Princess Margarite suffered a miscarriage (sometime between December 1497 and January 1498) as different versions within the oral tradition mention the hopes that her pregnancy implied for succession (Catalán 1988: 88). These ballads were also transmitted by means of personal notebooks in which their owners wrote poems that they had committed to memory or copied others from manuscripts or printed sources. As Paloma Díaz Mas points out «precisamente en uno de esos cartapacios de uso personal del siglo xvi se encontró hace unos años la única versión antigua conocida de La muerte del príncipe don Juan, un romance noticiero sobre el fallecimiento en 1497 del heredero de los Reyes Católicos, que debió de componerse a raíz del hecho que narra y del que hasta este descubrimiento en un cartapacio sólo se conocía por las versiones que habían pervivido en la tradición oral moderna» (2008: 15). 
dynamics of the social field, the political structure, and the psychological mindset at the end of $15^{\text {th }}$ Century Iberia.

All of the above, then, suggests that reading Calisto against the backdrop of Prince Juan situates the latter as a plausible antecedent for Rojas' character within the tradition of love as an illness in which Celestina emerges. As a literary archetype, Calisto recycles a historical model of exemplarity and excess as represented by Prince Juan. They both are part of the same tradition of extreme lovers that left its imprint on the collective imaginary at the end of the $15^{\text {th }}$ century in the Iberian Peninsula. Rojas' creative process, however, was not limited to simply recasting the archetype provided by Prince Juan. Working within the tradition of wretched lovers that populated the literary and social arena of his time, Calisto reconfigures the redeeming prototype of the "prince who died of love.» By condemning Calisto, Rojas directed his audience to the cautionary tale of those who love excessively and die a bad death, thus placing emphasis on love as the ultimate force that destroys the individual at the end of $15^{\text {th }}$ Century in Iberia. 


\section{Works Cited}

AlCALÁ, Ángel and Jacobo Sanz (1999), Vida y muerte del príncipe don Juan, Valladolid, Consejería de Educación y Cultura de la Junta de Castilla y León.

ArIĖs, Philippe (2000), The Hour of Our Death, Trans. Helen Weaver, New York: Barnes and Nobles.

ARIAS y ARIAS, Ricardo, ed. (1992), Andrés el Capellán, Tratado del amor cortés, Editorial Porrúa: México D. F.

Arovich DE BoGADo, V. H. (1992), "Textualizaciones orales de La muerte del Príncipe Don Juan' y de David llora a Absalón recogidas en Corrientes", in Actas del Congreso Argentino de Hispanistas: España en América, América en España, Buenos Aires, Instituto de Filología y Literatura Hispánica.

Aurell Cardona, Jaume (2002), "La impronta de los testamentos bajomedievales: entre la precariedad de lo corporal y la durabilidad de lo espiritual», in Ante la muerte. Actitudes, espacios y formas en la España medieval, eds. Jaume Aurell y Julia Pavón, Pamplona, EUNSA, pp. 77-93. Azcona, Tarsicio (1992), "El príncipe don Juan, heredero de los Reyes Católicos en el v Centenario de su nacimiento (1478-1497)», Cuadernos de Investigación Histórica, pp. 219-243.

BARTHES, Roland (1986), "The Death of Author", in The Rustle of Language, trans. Richard Howard, New York, Hill and Wang, pp. 49-55.

Barzun, Jacques (2000), From Dawn to Decadence. 500 Years of Western Cultural Life, New York, Haper Collins Publishers.

BAUTISTA, Francisco (2004), "La Crónica carolingia (o Fragmentaria): entre historiografía y ficción», La Corónica 32.3, pp. 13-34.

- (2008), «Realidad social e ideológica en La Celestina», Celestinesca 32, pp. 37-49.

BERNDT, Erna Ruth (1963), Amor, muerte y fortuna en "La Celestina», Madrid, Editorial Gredos.

Bertini, Giovanni María, ed. (1983), Alonso Ortiz, Diálogo sobre la educación del Príncipe don Juan, hijo de los Reyes Católicos, Madrid, José Porrúa Turanzas.

CANET, José Luis (1997), "'La Celestina' y el mundo intelectual de su época», in Cinco siglos de Celestina: Aportaciones interpretativas, eds. Rafael Beltrán and José Luis Canet, Valencia, Universidad de Valencia, pp. 43-60.

- (1996), «Los penitenciales: posible fuente de las primitivas comedias en vulgar», Celestinesca, 20.1-2, pp. 3-20.

Castro, Américo (1929), Santa Teresa y otros ensayos, Madrid, Historia Nueva. 
Catalán, Diego (1998), Arte poética del romancero oral. Parte $2^{a}$. Memoria, invención, artificio, Madrid, Siglo Veintiuno de España Editores.

DE VRIES, Henk (1999), "Ballads, Literature, and Historical Fact: 'Voces corren', Celestina, Don Quijote», Jahrbuch für Volksliedforschung, 44, pp. 13-23.

Díaz Mas, Paloma (1993), Romancero, Barcelona: Crítica.

- (2008), "El Romancero, entre la tradición oral y la imprenta popular», Destiempos 3.15, pp. 115-129.

Escudero de la Peña, José María, ed. (1870), Gonzalo Fernández de Oviedo y Valdés, Libro de la cámara real del príncipe Don Juan e offiçios e su casa e serviçio ordinario, Madrid: Viuda e hijos de Galiano.

Fabié, Antonio María (ed.) (1886). Algunas obras del doctor Francisco López de Villalobos. Madrid, Sociedad de Bibliófilos Españoles

Fernández Álvarez, Manuel (1975), Corpus documental de Carlos V: 15391548, 5 volumes, Salamanca, Universidad de Salamanca.

Gago Jover, Francisco, ed. (1999), Arte de bien morir y Breve confesionario, Barcelona y Mallorca: Liberduplex y Universidad de las Islas Baleares.

Gilman, Stephen (1978), La España de Fernando de Rojas. Panorama intelectual y social de "La Celestina", Madrid, Taurus.

Gómez ImAz, Manuel (1890), Algunas noticias referentes al fallecimiento del principe don Juan, hijo de los Reyes Católicos, Sevilla, E. Rasco.

Gómez Moreno, Manuel and Juan Mata Carriazo, eds. (1962), Andrés Bernáldez, Memorias del reinado de los Reyes Católicos, Madrid, Blass, S.A. Tipográfica

Herrera, María Teresa, ed. (1973), Francisco López de Villalobos, El sumario de la Medicina con un tratado de las pestíferas bubas, Instituto de Historia de la Medicina Española, Salamanca, Universidad de Salamanca.

López de Toro, José, ed. (1953), Pedro Mártir de Anglería, Epistolario, Volumes IX-XII, Madrid, Imprenta Góngora.

Marciales, Miguel, ed. (1985), Celestina. Tragicomedia de Calisto y Melibea by Fernando de Rojas, 2 Volumes, Urbana and Chicago, University of Illinois Press.

Márouez Villanueva, Francisco (1993), Orígenes y sociología del tema celestinesco, Barcelona, Antropos.

Maura Gamazo, Gabriel (2000), El Príncipe que murió de amor. Don Juan, Primogénito de los Reyes Católicos, Madrid, Alderabán Ediciones.

MazzocchI, Giusseppe (1988), "La Tragedia trobada de Juan del Encina y las Décimas sobre el fallecimiento del Principe nuestro señor del Comendador Román: dos textos frente a frente», Il Confronto letterario, 5, pp. 93-123.

Pérez-Bustamante, Rogelio and José Manuel Calderón Ortega (1999), Colección diplomática del Príncipe Don Juan (1478-1479), Madrid: Editorial Dykinson.

Pérez Priego, Miguel Ángel (2007), «La literatura en torno al príncipe don Juan: Crónicas y romancero», in Isabel la Católica y su época. Actas del Congreso Internacional Valladolid,2004, eds. Luis Antonio Ribot García, 
Julio Valdeón Baruque, and Elena Maza Zorrilla, 2 Volumes, pp. 12311239.

Rico, Francisco (1993), El sueño del humanismo (De Petrarca a Erasmo), Madrid, Alianza Editorial.

Rodríguez Puértolas, Julio, ed. (1996), La Celestina, Madrid, Ediciones Akal.

Rojas Mayer, Elena (2001), "La Construcción del contexto de 'La Celestina' a través del texto", in 'La Celestina' V Centenario (1499-1999). Actas del Congreso Internacional, eds. Felipe Pedraza Jiménez, Rafael González, and Gema Gómez Rubio, Cuenca, Universidad de Castilla la Mancha.

Rucouor, Adeline (1986), «De la resignación al miedo: la muerte en Castilla en el s. XV", in La idea y el sentimiento de la muerte en la historia y en el arte de la Edad Media (I), Santiago de Compostela: Universidad de Santiago de Compostela, pp. 51-66.

Rutherford, John (2001), "Laughing at Death: Act XIX of the Tragicomedia de Calisto y Melibea», Bulletin of Hispanic Studies, 78, pp. 167-176.

Sánchez-Molero, José Luis Gonzalo (1999), «El Príncipe Juan de Trastámara, un exemplum vitae para Felipe II en su infancia y juventud", Hispania, 59.3, n. 203, pp. 871-896.

Sanz Hermida, Jacobo, ed. (2000), Tratado del fallesçimiento del muy inclito señor don Juan, Ávila, Institución Gran Duque de Alba.

Senif, Dennis (1986), «Bernardo Gordonio's Lilio de Medicina: A Possible Source of Celestina?», Celestinesca, 10.1, pp.13-18.

Severin, Dorothy, ed. (1998), Fernando Rojas, La Celestina, Madrid, Ediciones Cátedra.

Strohm, Paul (2000), Theory and the Premodern Text, Minneapolis: University of Minnesota Press. 



\section{Sánchez y Sánchez, Samuel, «Prince Juan and Calisto: Reflections on a Historical Antecedent for a Literary Archetype», Celestinesca 40 (2016), pp. 159-192.}

\section{RESUMEN}

A través del examen del contexto cultural en el que surge Celestina (Salamanca, 1497-1499), este trabajo contribuye al estudio de las fuentes que influyeron en el proceso creativo de Fernando de Rojas. Específicamente, este artículo parte de los conceptos del exceso y la ejemplaridad para comparar la legendaria vida amorosa y la muerte ejemplar del Príncipe Juan - el primogénito de los Reyes Católicos que falleció en Salamanca en 1497- con la pasión erótica y la mala muerte de Calisto y sugerir que el príncipe pudo servir de modelo para el personaje de Calisto. El análisis de las representaciones literarias del Príncipe Juan y Calisto también ilumina la manera en que Rojas negoció la función literaria y el uso didáctico del concepto del exceso para reconciliar la aparente contradicción entre las reglas para amar y morir bien en los albores de la modernidad en la Península ibérica.

Palabras ClaVe: Príncipe Juan, Calisto, ejemplaridad, amor, muerte.

\section{ABSTRACT}

The present essay contributes to the study of the sources that inspired Fernando de Rojas' creative process by examining Celestina's immediate cultural context of production: Salamanca, 1497-1499. More specifically this article compares the legendary love life and model death of Prince Juan, the firstborn son to the Catholic Kings, who died in Salamanca in 1497 to the erotic passion and bad death of Calisto through the lenses of excess and exemplarity in order to suggest that the prince may have served as a model for Calisto. By bringing together the literary representations of Prince Juan and Calisto, this essay also illuminates the ways in which the literary and didactic functions of excess were negotiated by Rojas to reconcile the apparently contradictory instructions for how to both love well and to die well at the dawn of modernity in Iberia.

KEY WORDS: Prince Juan, Calisto, exemplarity, love, death.

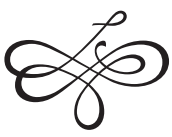

